By HENRY B. VAN HOESEN

\title{
Friends of the Library of Brown University
}

Mr. Van Hoesen, librarian of Brown University, read this paper at the meeting of the Friends of Libraries, June 23, 1942.

I SHOULD LiKe to change this title to 1 "The Friends of the Library of Blank University" and change my name to " $X$ " so that anything I say might not be used against me. For, since there is more than one side of everybody, corporeal or corporate, and since it may be novel at least to look at something else than the handsome ensemble, I am going to begin the description with what we might call the patch on the seat of the trousers, the wart on the end of the nose, or something like that. You will visualize this minor monstrosity most clearly if I quote a remark made by the librarian's secretary when the executive committee of the Friends gave her an opportunity to comment on a somewhat jubilant report of progress: "If you want to know what I think, the Friends of the Library are just a big headache to me."

I hope there are no reporters present foolish enough to think of making a newspaper feature of this paper, but if there are-Gentlemen, please, the headline is not " 'Friends of the Library a Headache,' Says Librarian" but "Friends of the Library Get Big Laugh When Told They're a Headache." For that's exactly what happened, and it is no small achievement for the Friends of the Library to under- stand just what you mean when you tell them they are a headache.

Perhaps, for the benefit of those of you who are not as well educated or library trained as the Friends of the Library of Blank University, I ought to explain the librarian's secretary. The librarian's secretary is a very busy person; she does not merely write letters at dictation and file correspondence, interview applicants, check and tabulate staff time cards, and, in general, do what you tell her; she tells you what to do-in other words, runs the office. To her then, at best, the Friends of the Library are an interruption and, necessarily during their early period of organization and promotion, the interruptions may be frequent and even long. Beginning with a chairman and half a dozen other self-appointed or co-opted officers, no office, no secretary, and a treasury with nothing in it, what else could they do but ask the librarian's secretary to tell them who to write to, to write their letters, to proofread their printed notices and bulletins, and criticize their style, and so on. The situation improves, of course, as the membership increases and the treasury gets something in it; it is possible to farm out more typing, mimeographing, and printing; but the Friends of the Library will always deserve the best assistance the library can give them, and even when they can afford a first-class secretary of their own, they will ask 
whether the money should be spent that way or on books for the library. One of Librarian $X$ 's pipe dreams is that the Friends of the Library of Blank University will some time have its own office and its own secretary, not entirely disconnected from the library and the librarian's office, but located near and helping to operate, let us say, the browsing room, which might be named the "Friends of the Library Room" and serve both Friends and students for recreational reading and for occasional meetings.

\section{The Librarian and the Friends}

The librarian's time, also, incidentally, is occasionally diverted to the activities of the Friends of the Library-at Blank University they insisted on making him honorary chairman, and the distinction between honorary (spelled with an $h$ ) and onerary (o-n-e-r-a-r-y) is sometimes very slight. But that is to be expected, of course-only, Librarian X's secretary says that he sometimes persuades his callers to stay longer than they really need to.

The Friends of the Library of Blank University have meetings-general meetings half a dozen times a year, meetings of the advisory committee once or twice a year, and meetings of the executive board once a month. Date, place, luncheon or dinner arrangements, speakers, business docket, etc.- -all to be discussed, arranged, and rearranged. The chairman will ask "about when should we have another meeting?" The chairman of the program committee will ask "what speaker do you want me to get?" The librarian's secretary will telephone the chairman, "Have you forgotten that you have to appoint a nominating committee?" or tell the secretary of the Friends, "No, you can't change constitution or by-laws without special advance notice of what the proposed amendment is," and so on. You might not expect it, but arranging the place of meeting is one of the big headaches. The Friends of the Library of Brown University consider their prime objective as educational and so they like to meet in different places-in different rooms in the university library, in the home libraries of some of the members, and even in other local institutional libraries-and they like to hear about these collections and see, more or less on display, the university's divisional library of biological sciences, Pembroke College Library, the Lincoln collection, the bookplate collection, the collection of war propaganda, the John Carter Brown Library, and so forth. This is an excellent policy, of course, but the headache is, how many of the four hundred Friends will be present and how many friends will they bring with them? Will the reading room adjoining the collection they want to see be large enough to hold them, or will the staff have to set up an exhibition from the collection somewhere else? And if the meeting place is to be a private home, will the house hold them, and, since the hostess insists on refreshments, how many shall she provide for?

\section{Additional Work}

"But," many of you may say, "such extracurricular activities are to be expected; they may be new or strange to university libraries but not so to public libraries." So let us note some of the additional work involved for the library's intramural processes and routines. I have already mentioned the additional number of special exhibitions, the subject, time, and place of which is set for, instead of by, the special collections staff. The special col- 
lections staff, the reference and circulation departments, and the divisional libraries receive more calls and inquiries from people outside the university. These people would have been welcome before but they hesitated to make a nuisance of themselves (as they say)-particularly if they are not alumni. This is all very gratifying, and the more and the oftener they come, the happier the library staff will be, but it is not to be denied that it adds to the service burden-particularly, as one would expect at the present time, in the division of mathematics, physical sciences, and engineering.

The order department of the library must be prepared to welcome but also to beware the Friends bearing gifts, for, while their prime objective is self-education, they are also, in the first paragraph of their first circular, "interested in the library of Brown University and its growing usefulness"-in fact, many of them say they would have no interest in the organization if it were not a help to the library. They announce that "gifts of books from members' libraries are welcome as additions to the resources of the library;" they encourage scouting in other people's attics as well as their own; they point out to lawyer friends that the library part of an estate may be settled quickly, easily, and satisfactorily by turning it over to the library of the university. So gifts of books come in-and again, the more they come, the better for the library. But, again, there is no denying that the sorting, selecting, searching, cataloging, and storage cost the library something; and the work of finding a home for the discards (perhaps two thirds of the whole gift) by sale at nominal prices to the library clientele or by exchange to other libraries, is a chore, however fascinating and however useful educationally it may be. Incidentally, the difficulty we used to hear about, of the donor's overprizing his gift and wanting it to be safeguarded forever as a memorial or special collection, has not been a problem in Librarian X's experience. His greater problem has been with people who overmodestly find it hard to believe that any of their "old junk" would be of any use to a great university library, and these people are the more pleased and encouraged to give when they understand that the library will not burden itself with books it cannot use but that any useful book will still find a useful place somewhere.

\section{More Work of Same Kind}

All this is simply a little more work of the same kind that the library staff has been doing all along the line. A certain amount of new routine becomes necessary in acknowledging, recording, and reporting gifts-more punctilious and more detailed. The gifts must all be counted, so that the Friends of the Library may know that between February 1939 and June I942 their net brought in thirteen thousand items. (Most of the individual Friends also like to know the extent of their gifts as they make them, but some of them object violently to having even a postcard wasted on them.) There should be a donors' file or directory, giving name, address, university connection (class numerals and all), dates of gifts, character of gifts. The librarian's report, as well as the bulletin published by the Friends, should publish lists of donors, and the lists should be correct. I don't know which is worse-omission or misspelling of names. One retired colonel-quite properly-protests the omission of the title in listing another colonel's name and the in- 
clusion of it in still another case where the man was "only a Governor's Colonel." Another time it is reported to the librarian: "So-and-so, one of your book-a-year men, is mad at you because his name does not appear in the last annual report."

Another new list is an alumni bibliography on cards-one for each alumnus author with the titles of all his books and articles as they appear in the library cata$\log$, the U.S. Catalog, and the Readers' Guide. The archivist (an honorary member of the library staff and a vice chairman of the Friends) then asks each alumnus to complete his own bibliography and complete the library's holdings of his publications. The initial cost of compiling this list at Brown University was contributed by the archivist himself and two other Friends, but the list changes almost from day to day as the replies come in, as new alumni go out, and as old alumni write new books.

\section{Description of Gifts}

The most difficult task, if it is done well, is the description of gifts. Friends would like to know just how their particular gifts will be useful to the library. Librarian $X$ often says "there should be a news story in every book that comes into the library," and some member of the library staff should be able to tell it, but most general libraries have too few specialists on their staffs to tell all the good stories.

In giving you so much of the headache, I find that the things I have featured as troublesome are at the same time some of the attractive features of the Friends of the Library organization. Not that headaches are a good thing for already overworked members of the library staff all along the line, but foresight of and, so far as possible, provision for additional work in the library will save some of the headache and enhance the desirability of the additional items of work. For they are desirable-some in themselves, some in their social and educational by-products, and all in the promise they hold for the improvement of the library on the one hand and alumni education on the other.

The meetings of the executive board are good fun in themselves-and without benefit of cocktails. The secretary's brief minutes of brief matters of business have, unhappily, failed to report the conversations in which so many projects have been so merrily sidetracked or wisecracked off the docket. For example, the librarian suggests the purchase of a collection of twenty thousand autographs, adding "and if no one will give the money, the man would like a loan, depositing the collection as security, and allowing us free. use of the twenty thousand autographs;" and the answer is, "On twenty thousand signatures the bank ought to loan him the money."

\section{General Meetings}

The general meetings also are good shows, once you are sure you have enough chairs for the audience and enough audience to fill the chairs-imported librarian speakers like Sir Angus Fletcher, Louis A. Warren, and George Parker Winship, and no lack of home talent, both town and gown. One of the most enjoyable meetings at Brown University was on the centennial of the birth of John Hay (for whom the library building was named), graced by the presence of Clarence $\mathrm{Hay}$, addressed by three members of the faculty on "John Hay as a Statesman" and "John Hay as a Poet," with readings of his poetry and accompanied by a John Hay 
exhibition drawn from the university library and the John Hay collection of one of the Friends. One of the largest meetings was a concert, on the occasion of the music librarians' conference at Brown and attended also by members of some dozen music clubs of Providence. The program was Rhode Island music-old songs selected from the Harris Collection of American Poetry and modern orchestral music on such recent themes as the hurricane of 1938.

Friendship is a mutual, not a one-sided relationship. The Friends of the Library should be beneficiaries as well as benefactors. Thus, in the long-range objective, the general meetings figure as part of a program of alumni education, along with the privilege of use of the library resources and services and the leaflet or pamphlet serial, Books at Brown. Members are invited to form special reading and discussion groups according to their special interests. Future plans include a special series of lectures on books-e.g. "Reading about the War," "Reading Plays," and so forth. The publishing of reading lists may follow if and as interest in them develops.

\section{Gifts of Books}

The gifts of books are, of course, a direct benefit to the library, and the byproduct of discards brings in a small revenue from sales and helps in exchange relations. The increase of work in the readers' service division is what the library is for and, in part, can fairly claim to have been an early beginning of the library's war effort. And if the improvement of the handling of gifts and the compilation of the alumni bibliography were long overdue, the satisfaction of accomplishment should be none the less.
I have not discussed gifts of money before because I could not think of any headache connected with them, but there have been gifts of money, in spite of the announced policy "Solicitation of funds is not the aim of this organization." Eleven Friends divided the purchase cost of a first edition of Isaac Newton's Principia Mathematica; seventy Friends contributed $\$ 900$ toward rounding out the George Earl Church Collection on South America; two Friends have started a Lincolniana fund with $\$ 300$; one Friend has given $\$ 150$ for the purchase of archives material; another has been giving $\$$ Ioo a year for books in various fields; another has transferred to the library his book royalties; and so on.

I did mention the gift for the compilation of the alumni bibliography-about ten months' salary-and there have been other gifts toward the salary budget. Industrial concerns have contributed $\$ 185$ in recognition of the reference service they have received from the physical sciences and engineering division. Several onebook gifts have been accompanied by dollar gifts to pay for cataloging and some by two-dollar gifts to pay for cataloging and housing. One gift of one thousand dollars was to be divided approximately two thirds for books in American history and other special subjects and one third for cataloging. Finally, the most recent gift is for the beginning of a fund for an extension of the library building and the increase of the library staff.

\section{Significance of Gifts Is Large}

No gift to the library-and no book added to the library-is insignificant, and if the aggregate of the examples I have selected does not seem large to some of you, their significance for the future de- 
velopment of the library is large. The future of endowed colleges depends on the support of their alumni, the support of the alumni depends upon their interest, and their interest is conditioned on their understanding. In other words, the active interest in the university and in the library is an educated interest. Of all the college activities the easiest thing for the alumnus in the street to understand is apparently intercollegiate athletics, and it may be that it's not even the athletics but merely the competition that he understands; in any case, it is much more difficult to "sell" him the academic activities and objectives of the college.

\section{Interest in Rare Books}

In the library objectives there is nothing really easy to understand and get enthusiastic about, such as athletics. I have sometimes thought of the acquisition of rare books as the nearest analogy. I mention this with some hesitation, for fear that I shall be misunderstood and give ammunition to Randolph Adams for another paper on "Librarians as Enemies of Books." What I mean to say is that just as a man may be enthusiastically interested in an athletic competition without knowing what the college is all about or even what the real significance, purpose, and use of college athletics are, so the element of competition in the rare book market ("Unique copy," "Only six other copies known," "Edition limited to 250 copies," etc.) may arouse the interest of a man who does not understand what the library is all about or what the rare book is all about. And this would not be so bad for libraries if rare books came as cheaply as admission to the bleachers-the alumnus in the street does not have the price of a really rare book and does not understand that the library needs a lot of five-dollar books; and so the library gets neither from him.

\section{One Donor and His Gifts}

Before the days of Friends of Libraries, I once suggested to a generous donor the purchase of some $\$ 2000$ worth of scientific books-things like the Abhandlungen, Denkschriften, and Sitzungsberichte of the K. Preussische Akademie der Wissenschaften zu Berlin. The gentleman did not seem the least bit excited but he did express interest in a single volume-the first issue of Walt Whitman's Leaves of Grass. When I showed him that the "points" of this issue were about like those of a postage stamp, he laughed and said, "You ought to be ashamed, making fun of the old man and his collecting." So the compromise was that he gave the library the first issue of Leaves of Grass and the British Museum Catalogue of Books. Now, of course, this friend is not an example of the alumnus in the street but his reactions illustrate my point about the collector's competitive inclinations. $\mathrm{He}$ also illustrates my other point-educated interest in the library. He was interested in Whitman's points, definitely not interested in Whitman (so he said), keenly interested in the library, and convinced that the book was a good thing for the library to have. The case of the British Museum Catalogue is certainly a case of educated interest.

To this group of gifts and the variety of more recent Friends gifts I have mentioned, inspired by an interest educated even up to the point of contributions to the cost of cataloging, I want to add one more specimen, a poem by the editor of Books at Brown, called "The Cataloger."

(Continued on page 17) 
marily directed at the state of Iowa. Within the state it is limited to fields not covered by the State University of Iowa Libraries or by the State Traveling Library. Outside of the state the library's resources have been made available wherever such service could not be rendered by corresponding institutions. The library's war program has been designed to promote efforts toward greater cooperation among research libraries that were developing so rapidly in the prewar years.

The work of the Iowa State College Library as described in this paper is probably not unique. Certainly all libraries could be much more active in providing war services than they are at present. For example, it is planned this summer at the Iowa State College Library to review and evaluate the war program completely. The professional staff, with the cooperation of the faculty and the college's Committee on Civilian War Activities will study during the summer all possibilities for further war services which are needed but not now provided. A continuing policy of re-examination and reinterpretation of established policy is necessary if we are to make our maximum contribution to the war effort and to justify the place of the university library in a rapidly changing civilization.

\section{Friends of the Library of Brown University}

\section{(Continued from page Io)}

\section{The Cataloger}

Stone walls do not a prison make, it's said, Nor books a library-if they're not read. Full many a book may blush unseen, unless It feels the cataloger's deft caress.

Her loving touch makes hidden wonders known;

She stores the corn the author has but sown.

Each single book may shed a little light;

But grouped with others, it can vanquish night.

So, Cataloger, you must make the bed;

Tuck each book in; see that a prayer is said Against misplacement on the teeming shelves. There let it sleep, till prowling scholar delves

Deep in the stacks. Led by your pointing pen,

He wakes it gleefully-to live again.

When Friends of the Library wax lyric over cataloging, they must be going places!
It is the growth of this kind of educated interest that the Friends of the Library are building up. "The raising of money is not the chief desire of the Friends. It is not even an important one. ... This is a society of persons who are lovers of books, interested in the Library of Brown University and its growing usefulness." But they have raised money and they will raise more-inevitably, as interest and knowledge of library activities and needs increase. And whether they raise money or not, they are still a good alumni education organization, alumni education is a proper function of the university (whether the alumni are its own or somebody else's), and educated alumni are, in the long run, the university's best asset and, thus, assets of the university library. 